nephron

Practice
Nephron 2015;129:34-38

DOI: $10.1159 / 000369311$
Received: September 8, 2014

Accepted after revision: October 24, 2014

Published online: December 17, 2014

\title{
Chimerism and Tolerance Induction in Kidney Transplantation
}

\author{
Opas Traitanon ${ }^{\mathrm{a}, \mathrm{b}}$ Lorenzo Gallon ${ }^{\mathrm{a}, \mathrm{c}}$ \\ ${ }^{a}$ Comprehensive Transplant Center, Northwestern University, Chicago, Ill., USA; ${ }^{b}$ Department of \\ Medicine-Nephrology, Thammasart University Hospital, Pathumthani, Thailand; ' ${ }^{\mathrm{D}}$ Department of \\ Medicine-Nephrology, Northwestern University, Chicago, III., USA
}

\section{Key Words}

Chimerism · Tolerance $\cdot$ Kidney transplantation

\begin{abstract}
Chimerism is a state in which bone marrow hematopoietic stem cells from two genetically different animals coexist. To date, the approach has been used successfully to induce the state of immunologic tolerance in the animal models and is now being evaluated in clinical trials of both HLA-identical and HLA-mismatched living-donor kidney transplant recipients in some transplant centers with varying degrees of success. Although the results are promising, the current conditioning regimens are not optimal and longer-term follow up and multicenter studies are needed to ensure the efficacy and safety of the procedures.

(c) 2014 S. Karger AG, Basel
\end{abstract}

\section{Introduction}

The evolution of immunosuppressive therapies in the past two decades has led to lower rejection rates and improved recipient short-term allograft outcomes in kidney transplantation, without long-term improvement in allograft-survival. Chronic alloimmune injuries, as well as long-term toxicity of the current immunosuppressive drug regimens are still major concerns. Recent analysis has shown that chronic antibody-mediated rejection is one of the leading causes of late graft failure $[1,2]$. Induction of immunologic tolerance remains the ultimate goal to achieve the best long-term graft outcome and avoid drug toxicity. Though many strategies have been successfully used to induce the immunologic tolerance in rodent models, chimerism was the only strategy capable of inducing the immunologic tolerance in large animals and humans [3]. Here we review the current methods that have been used to induce chimerism state and immunologic tolerance in human kidney transplantation.

\section{Chimerism in Human Kidney Transplantation}

Chimerism is a state in which bone marrow hematopoietic stem cells from two genetically different animals coexist. To date, there are only a few centers that have experience in inducing tolerance by using chimerism approach; Stanford University, Massachusetts General Hospital (MGH) and our group at Northwestern University. Each of these centers used their own unique conditioning regimens to induce donor hematopoietic cell engraftment and used different post-conditioning protocols [46] (table 1).

The Stanford group used a conditioning regimen that included total lymphoid irradiation (TLI) and rabbit antithymocyte globulin in the recipients of HLA-matched kidney transplant. This regimen has been shown to be safe from graft versus host disease (GVHD) in the preclinical

\section{KARGER}

E-Mail karger@karger.com

www.karger.com/nef
(C) 2014 S. Karger AG, Basel

$1660-8151 / 14 / 1291-0034 \$ 39.50 / 0$
Prof. Lorenzo Gallon

Department of Medicine-Nephrology, Northwestern University

676 N. St Clair, Arkes Pavilion 1900

Chicago, IL 60611 (USA)

E-Mail L-gallon@ northwestern.edu 
Table 1. Comparison of different conditioning regimen in different transplant centers

\begin{tabular}{|c|c|c|c|}
\hline Centers & Current conditioning regimen & Donor cells & Post-transplant \\
\hline $\begin{array}{l}\text { Stanford } \\
\text { group [4] }\end{array}$ & $\begin{array}{l}\text { Total lymphoid irradiation, rabbit antithymocyte } \\
\text { globulin, intravenous methylprednisolone, } \\
\text { prednisone }\end{array}$ & $\begin{array}{l}\text { Peripheral blood } \\
\text { CD34+ hematopoietic } \\
\text { progenitor cells }\end{array}$ & $\begin{array}{l}\text { Mycophenolate mofetil for } 1 \text { month, } \\
\text { cyclosporine tapered at } 3 \text { months, } \\
\text { discontinued at } 6 \text { months }\end{array}$ \\
\hline $\begin{array}{l}\text { MGH } \\
\text { group [5] }\end{array}$ & $\begin{array}{l}\text { NKD03 protocol: cyclophosphamide, humanized } \\
\text { antiCD2 mAB, thymic radiation, intravenous } \\
\text { cyclosporine A or tacrolimus } \\
\text { Modified NKD03/ITN036 protocol: } \\
\text { cyclophosphamide, humanized antiCD2 mAB, thymic } \\
\text { radiation, intravenous cyclosporine A or tacrolimus, } \\
\text { rituximab, prednisone }\end{array}$ & $\begin{array}{l}\text { Unprocessed donor } \\
\text { bone marrow cells }\end{array}$ & $\begin{array}{l}\text { Tacrolimus slowly tapered and } \\
\text { discontinued at } 8 \text { months }\end{array}$ \\
\hline $\begin{array}{l}\text { Northwestern } \\
\text { group [6] }\end{array}$ & $\begin{array}{l}\text { Cyclophosphamide, total body } \\
\text { irradiation, fludarabine }\end{array}$ & $\begin{array}{l}\text { A bioengineered FDA- } \\
\text { regulated hematopoietic } \\
\text { stem cells enriched for } \\
\text { facilitating cells }\end{array}$ & $\begin{array}{l}\text { Mycophenolate mofetil discontinued } \\
\text { at } 6 \text { months, tacrolimus tapered at } \\
9 \text { months and discontinued at } 1 \text { year } \\
\text { if durable chimerism is present }\end{array}$ \\
\hline
\end{tabular}

models and in humans $[7,8]$. From 12 patients reported, 4 patients developed stable mixed chimerism for a followup period of more than 18 months, and 4 patients had transient chimerism that declined over 12 months posttransplant [4]. All 8 patients were successfully withdrawn from immunosuppressive drugs. However, 3 patients in the study rapidly lost the chimerism after induction and developed acute cellular rejection (ACR). All patients, including the ones with rejection, had good graft function up to 72 months post-transplant. These results demonstrated that even with successful induction of chimerism, there remains the possibility of losing chimerism and subsequent rejection during withdrawal of immunosuppressive drugs. Furthermore, the requirement of chimerism for successful immunospressive drug withdrawal was not proven [4], and TLI alone might be able to induce the immunologic tolerance without the need for donor hematopoietic stem cells [9]. Although there were no major complications, episodes of neutropenic fever, pyelonephritis and viral infections were reported (1 CMV, 1 EBV and 3 varicella zoster). Since the long-term graft survival and overall outcomes of HLA-identical living donor kidney transplants are remarkably good [10], the justification for induction of tolerance in these patients is questionable. The Stanford group also attempted to apply this protocol to the HLA mismatched kidney transplant recipients [11], but rejection occurred in three of four patients when immunosuppression was tapered [12].

The MGH group just recently reported the long-term results of the combined kidney and bone marrow transplantation in 10 HLA-mismatched patients [5]. The con-

Chimerism in Kidney Transplantation ditioning regimen included the combination of intravenous cyclophosphamide, humanized anti-CD2 $\mathrm{mAB}$, intravenous cyclosporine, and thymic radiation to be administered up to 5 days before surgery [5]. Kidney transplant was followed by intravenous infusion of unprocessed donor bone marrow with oral cyclosporine as a maintenance drug, which was then tapered and discontinued over several months. The protocol was later modified to include Intravenous Rituximab to control B cell responses after the initial result revealed 1 graft loss from severe acute antibody-mediated rejection (ABMR) and the development of donor specific antibody (DSA) or C4d deposition in the protocol biopsy in other patients. Nine patients (90\%) experienced acute kidney injury as a part of the 'engraftment syndrome' [13], the cytokine syndrome-like manifestations associated with the loss of chimerism and the return of recipient hematopoietic cells. Although 7 patients recovered either spontaneously or with treatment, 2 allografts failed to recover ( 1 associated with ABMR and 1 progressed to thrombotic microangiopathy associated with high tacrolimus levels) [5]. In all 10 patients, transient mixed chimerism was achieved up to 21 days post-transplant with donor marrow infusion. Despite the 2 graft failure observed in the early phase, the remaining patients were successfully withdrawn from maintenance immunosuppression. One patient then developed ACR 3 months following immunosuppression withdrawal, leading to allograft loss. Although the other patients continued to do well in the early years without immunosuppression, chronic active ABMR was detected in the 5-year protocol biopsy of one 
patient and MMF was re-started. Weak intermittent DSA was detected in another patient and the subsequent protocol biopsy at 6.8 years revealed transplant glomerulopathy and glomerulitis without C4d deposition meeting the 2013 Banff criteria for early stage C4d-negative ABMR. Another patient also developed C4d deposition in the protocol biopsy at 2 years without detectable DSA and one patient had recurrent disease (MPGN), which was treated by MMF. Overall, there was only one patient who doesn't have any evidence of alloimmune injury after 10 years. Regardless of the operational definition of tolerance; more than one year without immunosuppression, most of the patients in the MGH protocol clearly demonstrated an ongoing chronic antibody-mediated injury, indicating the inadequate control of $\mathrm{B}$ cell alloresponse with the current protocol. In contrast to the immunologic tolerance observed in the mouse models, in which the chimerism is persistent and involves the central deletion of the donor-reactive T cells [14], chimerism in the MGH protocol was transient and involved partial deletion of the preexisting T cell repertoire. Even with the loss of chimerism, in vitro study still showed the donor-specific hyporesponsiveness (DSH) in both mixed lymphocyte culture (MLR) and cell-mediated lympholysis (CML) assay without compromised third-party alloresponses $[15,16]$. Previous mechanistic studies suggest that the mechanisms of tolerance involve regulatory $\mathrm{T}$ cells in the early phase and deletion of the donor reactive $\mathrm{T}$ cells in the long term [16, 17]. However, most mechanistic studies focus on measuring the direct $\mathrm{T}$ cell alloresponse, and more studies involving humoral immune response as well as indirect $\mathrm{T}$ cell alloresponse are needed to better understand the immunologic tolerance induced by mixed transient chimerism. Except for the engraftment syndrome mentioned earlier, no other major complication was observed in the MGH regimen and all patients were free from GVHD. In the most recent report, the authors also compared the post-transplant complications of the tolerance group with another group of HLA haploidentical living donor kidney transplants receiving the conventional immunosuppressive regimen. The long-term complications associated with long-term drug toxicity including hypertension, hyperlipidemia, and new-onset insulin-dependent diabetes were significantly higher in the conventional group. More infectious complications requiring hospitalization and malignancy ( 2 patients with malignant skin lesion) were also noted in the conventional group [5]. However, the rate of graft loss, which is the primary outcome, was higher in the mixed chimerism group with the current conditioning regimen. In conclusion, immuno- logic tolerance can be achieved by inducing transient mixed chimerism using the current MGH protocol. However, long-term alloimmune injury is present in many of the patients and the conditioning regimen needs adjustments to minimize the engraftment syndrome and avoid chronic antibody-mediated injury. Furthermore, more patients with longer follow up are needed to assess the efficiency and safety of the protocol.

\section{Transient vs. Durable Chimerism}

Our group at Northwestern Memorial Hospital $(\mathrm{NMH})$ has developed bioengineered hematopoietic stem cells enriched for facilitating cells (FCRx). These bone marrow-derived facilitating cells are predominantly composed of a plasmacytoid precursor dendritic cell subpopulation and CD8+ T cells that do not express $\mathrm{T}$ cell receptors, which potently enhance engraftment of allogeneic hematopoietic stem cells [18] and limited numbers of syngeneic hematopoietic stem cells in conditioned recipients [19]. Facilitating cells induce the generation of antigen-specific, regulatory $\mathrm{T}$ cells in vitro and in vivo and potently prevent GVHD in the mice [20-22]. The conditioning regimen at NMH consisted of pre-transplant fludarabine, pre- and post-transplant cyclophosphamide, and $200 \mathrm{cGy}$ total body irradiation. Eight of 15 HLA mismatched patients who underwent this protocol developed high-level (>90\%) durable donor chimerism beginning 1 month after transplantation [23]. One patient developed atypical viral infection and bone marrow failure at 3 months post-transplant, which was rectified by infusion of autologous stem cells. However, he later developed sepsis and allograft loss and was subsequently re-transplanted with a living donor kidney. Six of 8 patients who had full chimerism were successfully withdrawn from immunosuppression and the other 2 patients were successfully weaned to tacrolimus monotherapy. Durable mixed chimerism was noted in two patients. Three patients in the protocol had only transient donor chimerism lasting several months (2 had reduced doses of FCRx and 1 was highly sensitized with high PRA at the time of transplantation) but in vitro proliferative assay by MLR and CML also demonstrated DSH despite the loss of chimerism [23]. One of them was subsequently withdrawn from MMF and later Tacrolimus based on the in vitro testing, but later developed subclinical Banff $1 \mathrm{~A}$ rejection in the 12-month protocol biopsy, which was treated successfully with intravenous corticosteroids and by increasing tacrolimus dosage to therapeutic range. A second patient with transient mixed chimerism also demonstrated similar subclinical rejection in his 6-month pro-
Traitanon/Gallon 
tocol biopsy despite stable renal function and DSH by in vitro testing. Complete failure of donor engraftment occurred in one subject who was highly sensitized at the time of transplantation, and developed tacrolimus-induced hemolytic uremic syndrome following transplantation. No patients in the protocol experienced GVHD or engraftment syndrome. Contrary to the tolerance observed in the MGH group after transient mixed chimerism, subclinical rejection was detected early in our two subjects with transient mixed chimerism upon tapering of immunosuppression despite the presence of DSH demonstrated by in vitro assays. In contrast, the patients who achieved durable chimerism were completely free of cellular infiltrates or manifestations of chronic rejection. Notably, a study from the MGH group in which there was solely transient mixed chimerism for a period less than 21 days, reported DSH by in vitro testing in their nonchimeric subjects, some of whom went on to experience rejection episodes [24]. This evidence suggests that, in the absence of durable chimerism, the in vitro MLR and CML assay, which mainly tested the direct donor alloreactivity, is not always predictive of successful weaning of immunosuppression without rejection. Based on these findings, nonchimeric recipients are maintained on low-dose immunosuppression rather than complete withdrawal. The patients need close monitoring for the development of chronic GVHD as well as the status of their chimerism. In conclusion, transient or durable chimerism was achieved in the majority of subjects treated with the target dose of FCRx and conditioning without GVHD or engraftment syndrome. Only durable chimerism allowed safe withdrawal of maintenance immunosuppression without the risk of rejection.

\section{Conclusions}

Immunologic tolerance to allogeneic kidney transplant in humans is possible by using a chimerism approach. Significant progress has been made in the past decade; however, important issues still need to be investigated:

(1) The current conditioning regimen still needs to be modified to achieve a higher rate of successful chimerism induction and reduce the risk of toxicity that potentially outweighs the therapeutic benefits. This is valid for protocols used in HLA-identical as well as in HLA mismatch kidney transplant recipients.

(2) Longer-term follow up and a larger sample of patients are needed to ensure the efficiency and safety of these approaches compared to the conventional treatment.

(3) If these protocols will be proven to be safe and effective in the long term, similar approaches to induce tolerance should be investigated for recipients of cadaveric renal transplants.

\section{References}

1 Einecke G, Sis B, Reeve J, Mengel M, Campbell PM, Hidalgo LG, Kaplan B, Halloran PF: Antibody-mediated microcirculation injury is the major cause of late kidney transplant failure. Am J Transplant 2009;9: 2520-2531.

- 2 El-Zoghby ZM, Stegall MD, Lager DJ, Kremers WK, Amer H, Gloor JM, Cosio FG: Identifying specific causes of kidney allograft loss. Am J Transplant 2009;9:527-535.

- 3 Leventhal J, Miller J, Abecassis M, Tollerud DJ, Ildstad ST: Evolving approaches of hematopoietic stem cell-based therapies to induce tolerance to organ transplants: the long road to tolerance. Clin Pharmacol Ther 2013;93: $36-45$.

-4 Scandling JD, Busque S, Dejbakhsh-Jones S, Benike C, Sarwal M, Millan MT, Shizuru JA, Lowsky R, Engleman EG, Strober S: Tolerance and withdrawal of immunosuppressive drugs in patients given kidney and hematopoietic cell transplants. Am J Transplant 2012;12:1133-1145.
5 Kawai T, Sachs DH, Sprangers B, Spitzer TR, Saidman SL, Zorn E, Tolkoff-Rubin N, Preffer F, Crisalli K, Gao B, Wong W, Morris H, LoCascio SA, Sayre P, Shonts B, Williams WW Jr, Smith RN, Colvin RB, Sykes M, Cosimi AB: Long-term results in recipients of combined HLA-mismatched kidney and bone marrow transplantation without maintenance immunosuppression. Am J Transplant 2014;14: 1599-1611.

-6 Leventhal J, Abecassis M, Miller J, Gallon L, Ravindra K, Tollerud DJ, King B, Elliott MJ, Herzig G, Herzig R, Ildstad ST: Chimerism and tolerance without GVHD or engraftment syndrome in HLA-mismatched combined kidney and hematopoietic stem cell transplantation. Sci Transl Med 2012;4: $124 \mathrm{ra} 128$.

7 Lowsky R, Takahashi T, Liu YP, DejbakhshJones S, Grumet FC, Shizuru JA, Laport GG, Stockerl-Goldstein KE, Johnston LJ, Hoppe RT, Bloch DA, Blume KG, Negrin RS, Strober $\mathrm{S}$ : Protective conditioning for acute graft-ver- sus-host disease. N Engl J Med 2005;353: 1321-1331.

-8 Kohrt HE, Turnbull BB, Heydari K, Shizuru JA, Laport GG, Miklos DB, Johnston LJ, Arai S, Weng WK, Hoppe RT, Lavori PW, Blume KG, Negrin RS, Strober S, Lowsky R: TLI and ATG conditioning with low risk of graft-versus-host disease retains antitumor reactions after allogeneic hematopoietic cell transplantation from related and unrelated donors. Blood 2009;114:1099-1109.

-9 Strober S, Dhillon M, Schubert M, Holm B, Engleman E, Benike C, Hoppe R, Sibley R, Myburgh JA, Collins G, et al: Acquired immune tolerance to cadaveric renal allografts. A study of three patients treated with total lymphoid irradiation. N Engl J Med 1989;321:28-33.

10 Shimmura H, Tanabe K, Ishida H, Miyamoto $\mathrm{N}$, Tokumoto T, Ishikawa N, Toma H: Longterm results of living kidney transplantation from HLA-identical sibling donors under calcineurin inhibitor immunosuppression. Int $\mathrm{J}$ Urol 2006; 13:502-508. 
$>11$ Millan MT, Shizuru JA, Hoffmann P, Dejbakhsh-Jones S, Scandling JD, Grumet FC, Tan JC, Salvatierra O, Hoppe RT, Strober S: Mixed chimerism and immunosuppressive drug withdrawal after HLA-mismatched kidney and hematopoietic progenitor transplantation. Transplantation 2002;73:1386-1391.

12 Millan MT, Shizuru JA, Lowsky R, Strober S: Studies of tolerance and chimerism after combined blood stem cell and kidney transplantation in humans. Am J Transplant 2005; (suppl 11):544.

$>13$ Spitzer TR: Engraftment syndrome following hematopoietic stem cell transplantation. Bone Marrow Transplant 2001;27:893-898.

14 Pilat N, Wekerle T: Transplantation tolerance through mixed chimerism. Nat Rev Nephrol 2010;6:594-605.

15 Kawai T, Cosimi AB, Spitzer TR, Tolkoff-Rubin N, Suthanthiran M, Saidman SL, Shaffer J, Preffer FI, Ding R, Sharma V, Fishman JA, Dey B, Ko DS, Hertl M, Goes NB, Wong W, Williams WW Jr, Colvin RB, Sykes M, Sachs DH: HLA-mismatched renal transplantation without maintenance immunosuppression. N Engl J Med 2008;358:353-361.
16 Andreola G, Chittenden M, Shaffer J, Cosimi AB, Kawai T, Cotter P, Locascio SA, Morokata T, Dey BR, Tolkoff-Rubin NT, Preffer F, Bonnefoix T, Kattleman K, Spitzer TR, Sachs DH, Sykes M: Mechanisms of donor-specific tolerance in recipients of haploidentical combined bone marrow/kidney transplantation. Am J Transplant 2011;11:1236-1247.

17 Fudaba Y, Spitzer TR, Shaffer J, Kawai T, Fehr T, Delmonico F, Preffer F, Tolkoff-Rubin N, Dey BR, Saidman SL, Kraus A, Bonnefoix T, McAfee S, Power K, Kattleman K, Colvin RB, Sachs DH, Cosimi AB, Sykes M: Myeloma responses and tolerance following combined kidney and nonmyeloablative marrow transplantation: in vivo and in vitro analyses. Am J Transplant 2006;6:2121-2133.

-18 Kaufman CL, Colson YL, Wren SM, Watkins S, Simmons RL, Ildstad ST: Phenotypic characterization of a novel bone marrow-derived cell that facilitates engraftment of allogeneic bone marrow stem cells. Blood 1994;84:24362446.

19 Grimes HL, Schanie CL, Huang Y, Cramer D, Rezzoug F, Fugier-Vivier I, Ildstad ST: Graft facilitating cells are derived from hematopoietic stem cells and functionally require CD3, but are distinct from $\mathrm{T}$ lymphocytes. Exp Hematol 2004;32:946-954.

20 Taylor KN, Shinde-Patil VR, Cohick E, Colson YL: Induction of FoxP3+CD4+25+ regulatory $\mathrm{T}$ cells following hemopoietic stem cell transplantation: role of bone marrow-derived facilitating cells. J Immunol 2007;179:21532162 .
21 Huang Y, Bozulic LD, Miller T, Xu H, Hussain LR, Ildstad ST: Cd8 alpha(+) plasmacytoid precursor DCs induce antigen-specific regulatory $\mathrm{T}$ cells that enhance HSC engraftment in vivo. Blood 2011;117:24942505.

22 Colson YL, Christopher K, Glickman J, Taylor KN, Wright R, Perkins DL: Absence of clinical GVHD and the in vivo induction of regulatory $\mathrm{T}$ cells after transplantation of facilitating cells. Blood 2004;104:3829-3835.

23 Leventhal J, Abecassis M, Miller J, Gallon L, Tollerud D, Elliott MJ, Bozulic LD, Houston C, Sustento-Reodica N, Ildstad ST: Tolerance induction in HLA disparate living donor kidney transplantation by donor stem cell infusion: durable chimerism predicts outcome. Transplantation 2013;95:169-176.

24 Farris AB, Taheri D, Kawai T, Fazlollahi L, Wong W, Tolkoff-Rubin N, Spitzer TR, Iafrate AJ, Preffer FI, Locascio SA, Sprangers B, Saidman S, Smith RN, Cosimi AB, Sykes M, Sachs DH, Colvin RB: Acute renal endothelial injury during marrow recovery in a cohort of combined kidney and bone marrow allografts. Am J Transplant 2011;11:1464-1477. 